\title{
Monitoring organic matter dynamics in soil profiles by 'Rock-Eval pyrolysis': bulk characterization and quantification of degradation
}

\author{
D. Sebag ${ }^{a}, J \cdot R$. Disnar ${ }^{b}$, B. Guillet ${ }^{b}$, C. Di Giovanni ${ }^{b}$, E. P. Verrecchia ${ }^{c}$ \& A. Durand $^{a}$ \\ ${ }^{\mathrm{a}} U M R$ CNRS 6143, Morphodynamique Continentale et Côtière, Département de Géologie, Université de Rouen, 76821 Mont Saint \\ Aignan Cedex, ' ISTO, UMR CNRS 6113, Bâtiment Géosciences, Université d'Orléans, BP 6759, 45067 Orléans Cedex 2, France, and \\ ${ }^{\mathrm{c} I n s t i t u t ~ d e ~ G e ́ o l o g i e, ~ R u e ~ E m i l e-A r g a n d ~ 11, ~} 2007$ Neuchâtel, Switzerland
}

\begin{abstract}
Summary
Rock-Eval pyrolysis was designed for petroleum exploration to determine the type and quality of organic matter in rock samples. Nevertheless, this technique can be used for bulk characterization of the immature organic matter in soil samples and recent sediments. We studied 76 samples from seven soil classes and showed that their pyrograms can be described by a combination of four elementary Gaussian components: F1, F2, F3 and F4. These four components are related to major classes of organic constituents differing in origin and their resistance to pyrolysis: labile biological constituents (F1), resistant biological constituents (F2), immature non-biotic constituents (F3) and a mature refractory fraction (F4). We discriminated the relative contributions of these components and used them to derive two indices: (i) to quantify the relative contributions of labile and resistant biological constituents and (ii) to quantify the degradation stage of the soil organic matter. The practical applications are illustrated via the influence of vegetal cover on soil organic matter dynamics and peat development in a Holocene sedimentary sequence, but we suggest that the approach is of much wider application.
\end{abstract}

\section{Introduction}

The components of soil organic matter (OM) are difficult to distinguish for practical and fundamental reasons, e.g. OM is a continuum between biological tissues (more or less wellpreserved plant, microbial and fungal fragments) and humic substances (e.g. Kögel-Knabner, 1993), and various anthropogenic substances mixed with the natural constituents (e.g. Schmidt \& Noack, 2000; Rumpel et al., 2001). Numerous techniques have been used to understand the dynamics of these components through analysis of soil OM (e.g. KögelKnabner, 2000), including analytical pyrolysis techniques to give detailed structural information at the molecular level (e.g. Leinweber \& Schulten, 1999; Magrini et al., 2002). However, very few of them are used routinely, because of the common need for preliminary sample preparation (e.g. decarbonation, extraction or purification).

The 'Rock-Eval' pyrolysis (RE pyrolysis) technique was designed for petroleum exploration, to screen automatically and without any preliminary treatment large sets of rock and sediment samples (Espitalié et al., 1977, 1985; Lafargue et al., 1998). Because of its simplicity, it has thus been used for a

Correspondence: D. Sebag. E-mail: david.sebag@univ-rouen.fr Received 18 March 2004; revised version accepted 29 April 2005 variety of materials it had not originally been designed for, e.g. soils and recent sediments (Disnar \& Trichet, 1984; Sifeddine et al., 1995; Di Giovanni et al., 1998, 1999; Disnar et al., 2000; Lüniger \& Schwark, 2002).

In this technique, bulk dried samples are heated in an inert atmosphere and, upon pyrolysis, the main emission products (hydrocarbons, $\mathrm{CO}_{2}, \mathrm{CO}$ ) are quantified by flame-ionization (FI) and infrared (IR) detection. These measurements are used to calculate several basic parameters, e.g. total organic carbon contents, thermal maturity, and the Hydrogen Index and Oxygen Index correlated to $\mathrm{H} / \mathrm{C}$ and $\mathrm{O} / \mathrm{C}$ values, respectively (Espitalié et al., 1977, 1985; Tissot \& Welte, 1984). These various parameters were defined to study the properties of mature OM from source rocks (e.g. Disnar, 1994), but recent work showed that they could be used to characterize immature OM from recent sediments (Ariztegui et al., 1996; Di Giovanni et al., 1998; Lüniger \& Schwark, 2002). For soils, these possibilities have been explored to study soil contamination (Lafargue et al., 1998) and through an analytical survey of profiles taken from different ecosystems (Disnar et al., 2003). However, these authors also showed that the values of thermal maturity and the Hydrogen Index limit their use considerably. This has led Disnar et al. (2003) to propose a study of the most significant class of pyrolysis curves from which thermal 
maturity and the Hydrogen Index are calculated. This paper pursues this purpose and aims to improve the 'Rock-Eval toolbox' and its potential for the study of soil OM by a morphological study of the most promising pyrolysis curves.

\section{Site descriptions and sampling}

We chose a total of 119 samples belonging to seven classes of soils from various localities to represent the diversity of ecological and pedogenic factors: density and type of vegetation, nature of the substratum, topography, hydrology and climate. A summary of the site characteristics is given in Table 1. The various soil layers were distinguished according to AFES (1995). Sampling was made with a manual borer and the samples were stored in the dark after oven-drying $\left(<40^{\circ} \mathrm{C}\right)$ and manual crushing.

Haute-Normandie (i.e. Seine catchment, $49^{\circ} 46^{\prime} \mathrm{N}, 1^{\circ} 28^{\prime} \mathrm{E}$ ) is in northwestern France about $60 \mathrm{~km}$ from the Channel coast and between 5 and $140 \mathrm{~m}$ above the sea level. The vegetation is dominated by mixed deciduous forests of beech (Fagus sylvatica) and oak (Quercus sessiliflora) and grassland. The climate is maritime; the precipitation is between 600 and $1100 \mathrm{~mm}$ annually, and the average annual temperature is between 10 and $12^{\circ} \mathrm{C}$. In Haute-Normandie, the nature of the substratum and the local hydrological conditions depend on the geomorphological context. Various forest soils with a permanent litter layer were sampled in a plateau context (underlain by Cretaceous limestone), in a slope context (underlain by Tertiary clays-with-flints), and in a valley context (underlain by Holocene alluvial deposits). These soils include a thick $\mathrm{OH}$ horizon rich in faecal pellets, overlying an $\mathrm{A}$ horizon comprising organic aggregates. In addition, a dry grassland profile was sampled in a plateau context (underlain by Cretaceous limestone). On the other hand, 15 samples of Histosols (i.e. more or less degraded peat) and a core of Holocene fluvio-palustrine deposits (core BLP2) were also collected in the Lower Seine Valley. This sedimentary fill includes clayey and sandy loams and a thick organic sequence (4-6 m). This peaty deposit corresponds to the settlement of a large wetland network between 5300 and 5000 years BC and 1000-750 years BC (Sebag, 2002).

Haute-Provence (i.e. Le Brusquet and Le Laval catchments, $44^{\circ} 13^{\prime} \mathrm{N}, 6^{\circ} 35^{\prime} \mathrm{E}$ ) is in southeastern France about $150 \mathrm{~km}$ from the Mediterranean coast and between 850 and $1250 \mathrm{~m}$ above sea level. Both catchments are part of the Draix experimental catchments studied by CEMAGREF (Grenoble, France). The vegetation is dominated by oak (Quercus sp.) in deciduous forests, by pine (Pinus sp.) in coniferous forest, and by graminaceous species in dry grassland. The climate is humid Mediterranean with annual rainfall of about $800 \mathrm{~mm}$, and annual average temperature is 10 and $12^{\circ} \mathrm{C}$. The bedrock is Cretaceous marls and limestones. The Brusquet $(\mathrm{Br})$ and the Laval (La) catchments are less than $3 \mathrm{~km}$ apart and differ only in the nature and density of their plant cover (Table 1). The

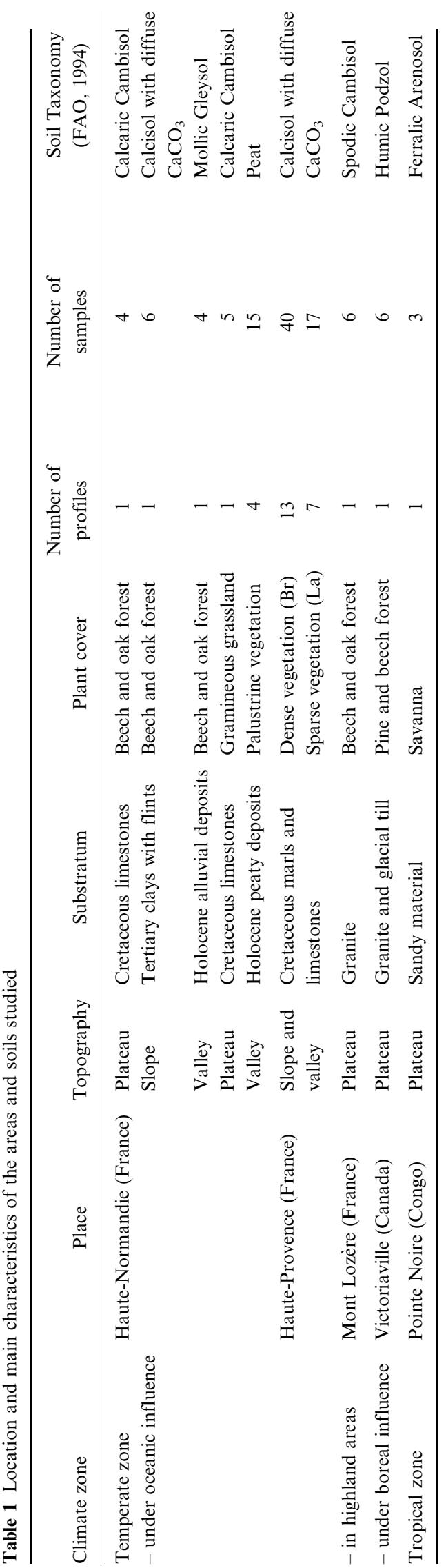


Brusquet catchment is covered by a dense pine and holly forest; the soils include a thick litter layer overlying an A horizon. The Laval catchment is covered by a sparse mixed deciduous, coniferous and graminaceous vegetation; the soils include a thin litter layer overlying an A horizon.

To consider the diversity of climatic conditions, some profiles studied by Disnar et al. (2003) have been added to the sampling. These include soil profiles of highland areas of the temperate zone (i.e. Mont Lozère, France; $44^{\circ} 30^{\prime} \mathrm{N}, 3^{\circ} 42^{\prime} \mathrm{E}$ ) that were collected under beech forest on granite. Soils include a thick forest litter with a well-developed $\mathrm{OH}$ horizon. The cold and humid climate of the boreal zone (i.e. Victoriaville, Canada; $46^{\circ} 03^{\prime} \mathrm{N}, 71^{\circ} 58^{\prime} \mathrm{W}$ ) is favourable to Podzol development on crystalline bedrock poor in clays and alterable minerals. Forest soils include a thick $\mathrm{OH}$ horizon rich in faecal pellets overlying an A horizon comprising organic aggregates juxtaposed to quartz grains. In the tropical zone (i.e. Pointe Noire, Congo; $0^{\circ} 53^{\prime} \mathrm{N}, 15^{\circ} 47^{\prime} \mathrm{E}$ ), the samples collected are typical ferralitic soils developed on sandy parent materials poor in clay.

\section{Methods}

Analyses were performed with a 'Turbo model Rock-Eval ${ }^{\circledR} 6$ pyrolyser' (Vinci Technologies, Rueil-Malmaison, France). About $100 \mathrm{mg}$ of crushed material was analysed by the 'Bulk Rock' method, in which the samples were heated at $30^{\circ} \mathrm{C}$ minute $^{-1}$ in $\mathrm{N}_{2}$ up to $650^{\circ} \mathrm{C}$ (Lafargue et al., 1998), and then in a stream of oxygen up to $850^{\circ} \mathrm{C}$ (oxidation; Espitalié et al., 1977).

\section{Curve types}

The amounts of the main emission products (hydrocarbons, $\mathrm{CO}_{2}, \mathrm{CO}$ ) are continuously measured by flame-ionization and infrared detection (Figure 1a; Lafargue et al., 1998): (1) $<200^{\circ} \mathrm{C}$; free hydrocarbon compounds; S1 curve; (2) 200-650 ${ }^{\circ}$; hydrocarbon compounds released during pyrolysis; S2 curve; (3) $200-650^{\circ} \mathrm{C} ; \mathrm{CO}_{2}$ and $\mathrm{CO}$ released during pyrolysis; $\mathrm{S} 3$ and $\mathrm{S}^{\prime} 3$ curves; (4) up to $850^{\circ} \mathrm{C} ; \mathrm{CO}_{2}$ and $\mathrm{CO}$ released during oxidation; $\mathrm{S} 4$ and $\mathrm{S}^{\prime} 4$ curves. Two parameters
Figure 1 (a) Typical signals measured during a Rock-Eval pyrolysis (the S1 curve is not shown). S2 (hydrocarbons), S3 and $\mathrm{S}^{\prime} 3$ (CO and $\left.\mathrm{CO}_{2}\right)$ curves are from pyrolysis. $\mathrm{S} 4$ and $\mathrm{S}^{\prime} 4\left(\mathrm{CO}\right.$ and $\left.\mathrm{CO}_{2}\right)$ curves are from oxidation of the residual carbon following pyrolysis. (b) Examples of S2 curves: pure organic substances (sugars, lignin, cellulose), fossil sediments (Carboniferous mature sedimentary $\mathrm{OM}$ ) and moder-type layers from grassland and forest soils. The temperature maxima represent thermal maturity (Tpeak). (a)
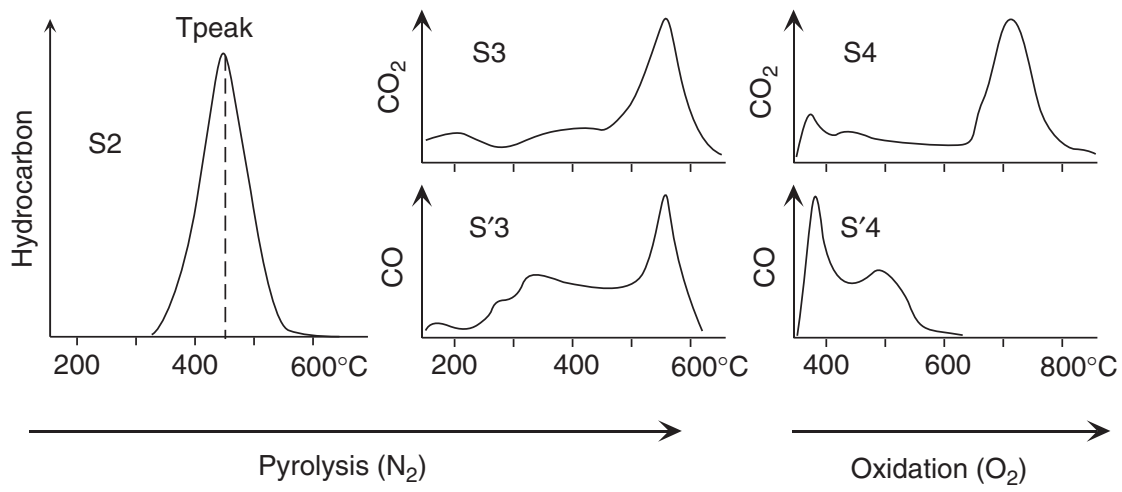

(b)
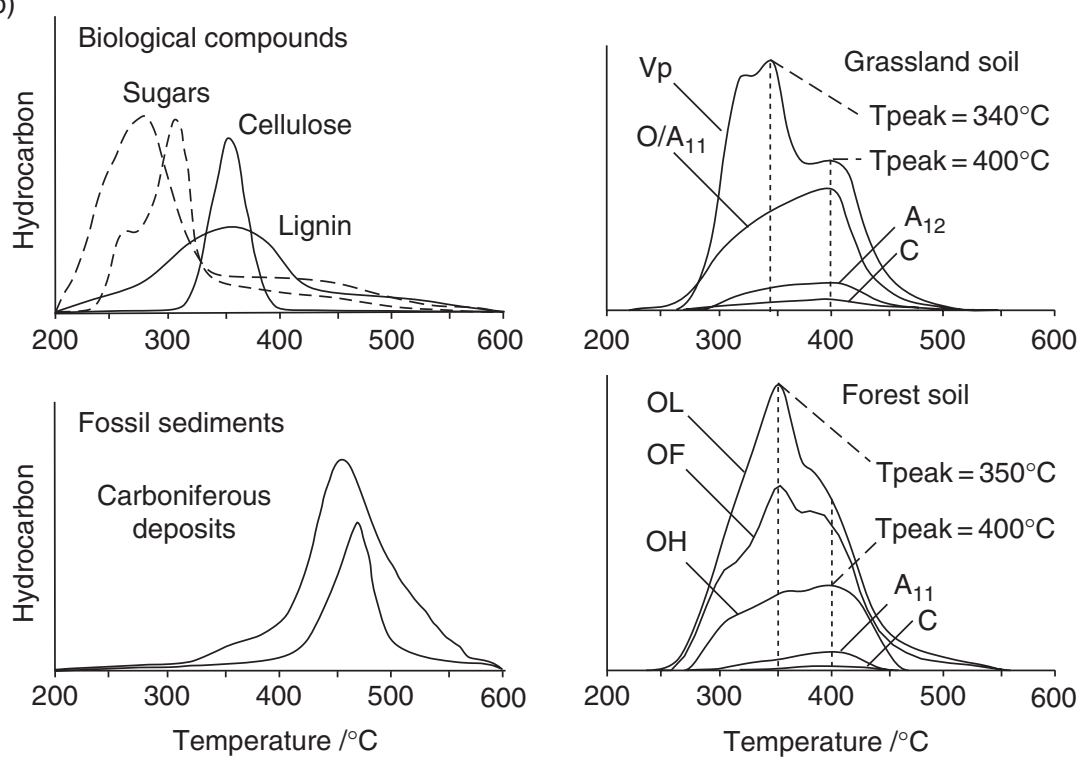
are calculated directly from the S2 curves: the thermal maturity (Tpeak; ${ }^{\circ} \mathrm{C}$ ), which measures the temperature at the maximum of the S2 curve (Figure 1a), and the Hydrogen Index (HI; mg hydrocarbon $\mathrm{g}^{-1}$ TOC), which measures the amount of hydrocarbons generated during pyrolysis normalized to the amount of organic carbon (Lafargue et al., 1998).

\section{S2 curve analysis}

Nevertheless, this classical approach, i.e. the use of automatically calculated parameters, leaves aside almost completely an important question raised by the shape of the S2 curves, on which the significance of the Tpeak is highly dependent (Figure 1b). In thermally mature samples, such as those normally analysed in petroleum exploration, these curves most frequently have a Gaussian-like shape, so Tpeak values can be rather easily characterized. In contrast, samples containing thermally immature OM, e.g. recent sediments and soils, frequently produce multilobed S2 curves (Disnar \& Trichet, 1984). In this case, the Tpeak only represents the dominant component of the signal with variable influence from the other components (Disnar et al., 2003). When two adjacent components have comparable intensities, the intermediate Tpeak values obtained are susceptible to rapid variations depending on the relative increase in the predominance of one (Figure 1b). In other words, the classical 'Rock-Eval' approach neglects the intensity and the position of the secondary components, i.e. the multilobed character of S2 signals, and this represents a loss of information with regard to curve shape.

Representative soil profiles presented in Figure 1(b) show that the shape of S2 curves changes progressively from surficial to deeper horizons, even though the Tpeak is not discriminant of the main steps of this evolution. The herbaceous plant $(\mathrm{Vp})$ curve gives a shoulder around $310^{\circ} \mathrm{C}$, a main mode, i.e. Tpeak, at $340^{\circ} \mathrm{C}$ corresponding to the maximum release of hydrocarbons, and a second shoulder around $400^{\circ} \mathrm{C}$. The forest litter (OL, OF horizons) curves show a Tpeak around $350^{\circ} \mathrm{C}$, a shoulder around $380^{\circ} \mathrm{C}$, and sometimes a slight change in slope around $300^{\circ} \mathrm{C}$. Humic layer $(\mathrm{OH}, \mathrm{O} / \mathrm{A})$ curves exhibit a Tpeak between $380^{\circ} \mathrm{C}$ and $400^{\circ} \mathrm{C}$, sometimes associated with two secondary modes around $300^{\circ} \mathrm{C}$ and $350^{\circ} \mathrm{C}$, respectively. Organo-mineral horizon samples (A horizons) show a Tpeak $\geq 400^{\circ} \mathrm{C}$. Despite these differences, the Tpeak temperatures are very close for $\mathrm{Vp}, \mathrm{OL}$ and $\mathrm{OF}$ horizons (from 340 to $350^{\circ} \mathrm{C}$ ) and similar for $\mathrm{OH}$ and $\mathrm{O} / \mathrm{A}$ samples $\left(400^{\circ} \mathrm{C}\right)$.

\section{Deconvolution of $S 2$ curves}

We deconvoluted the S2 curves into a combination of elementary components in order to quantify their morphological evolution. Mathematical or statistical techniques of signal analysis, e.g. derived function, wavelets, Fourier, are not easily applied to signals obtained from plant, soil or sediment samples. They are too sensitive to the small differences related to the natural variability of biological compounds. Unless smoothing the measured S2 signals, these automatic methods provide numerous elementary signals, which are not easily compared with each other.

We employed the residual method, which consists of subtracting the major Gaussian elementary distribution centred on the main mode, first from the initial S2 signal (Figure 2a), then from successive residual distributions (Figure $2 b$ ). If the relative maxima reach a predetermined threshold (Figure 2c), a numerical iterative process is used to optimize the parameters of the elementary Gaussian distributions (mean, standard deviation) while minimizing the residuals (Figure 2d). The goodness-of-fit is measured by correlation between the initial S2 pyrolysis signal and the sum of the four elementary components. This correlation is characterized by the correlation coefficient $(r)$.

This empirical approach arbitrarily reduces the number of elementary components. From previous results and a preliminary study (Table 2), we deconvoluted S2 curves into a combination of four elementary Gaussian components - F1 to F4. This seems reasonable as previous work has shown that Tpeak values from natural samples are mostly clustered in certain temperature ranges: $300-320^{\circ} \mathrm{C}, 360-380^{\circ} \mathrm{C}, 430-450^{\circ} \mathrm{C}$ or $>470^{\circ} \mathrm{C}$ (Di Giovanni et al., 1998; Noël et al., 2001; Disnar et al., 2003). On the other hand, this method assumes that we fixed arbitrarily the distribution of the elementary components used. As a first approximation, the use of Gaussian-like signals to deconvolute RE pyrograms (i.e. S2 curves) is justified by the shape of signals obtained for purified products (Figure 1b).

\section{Results of deconvolution}

The average contribution of the above-defined components is $25 \%$ for $\mathrm{F} 1,27 \%$ for $\mathrm{F} 2,30 \%$ for $\mathrm{F} 3$, and $17 \%$ for $\mathrm{F} 4$. Nevertheless, their contributions differ strongly from one sample to another, i.e. from 2 to $50 \%$ for $\mathrm{F} 1$, from 2 to $55 \%$ for $\mathrm{F} 2$, from 15 to $55 \%$ for $\mathrm{F} 3$, and from 2 to $36 \%$ for F4 (Figure 3a,b). Means for each type of horizon show trends, which are

Table 2 Results of preliminary studies performed on 20 soil samples. Restoration rate of initial S2 signal depending on the number of elementary Gaussian distributions. Minimum, maximum and mean Tpeak values $\left({ }^{\circ} \mathrm{C}\right)$ of elementary Gaussian components $\mathrm{F} 1$ to $\mathrm{F} 4$

\begin{tabular}{llllllll}
\hline Number of components & 1 & 2 & 3 & 4 & 5 & 6 & 7 \\
Restoration yield $/ \%$ & 76.1 & 80.7 & 93.8 & 99.2 & 99.3 & 99.8 & 99.9
\end{tabular}

\begin{tabular}{lcccc}
\hline & \multicolumn{4}{c}{ Tpeak of the four elementary Gaussian components $/{ }^{\circ} \mathrm{C}$} \\
\cline { 2 - 5 } & F1 & F2 & F3 & F4 \\
\hline Minimum & 285 & 363 & 423 & 460 \\
Maximum & 321 & 387 & 458 & 533 \\
Mean & 307 & 371 & 436 & 481 \\
\hline
\end{tabular}


Figure 2 S2 signal deconvolution by a residue method. (a) Step 1: subtraction of the major Gaussian elementary distribution centred on the main mode, i.e. Tpeak at $370^{\circ} \mathrm{C}$, from the initial S2 signal. (b) The residual distribution shows two relative maxima which correspond to two secondary modes. (c) Step 2: successive subtraction from the residual distribution until the relative maxima reach a predetermined threshold. (d) Step 3: iteration to optimize the parameters of the elementary Gaussian distributions (mean, standard deviation) while minimizing the residuals. Dotted curve: initial S2 signal. Hatched surface: information not restored by the deconvolution signal (residuals).
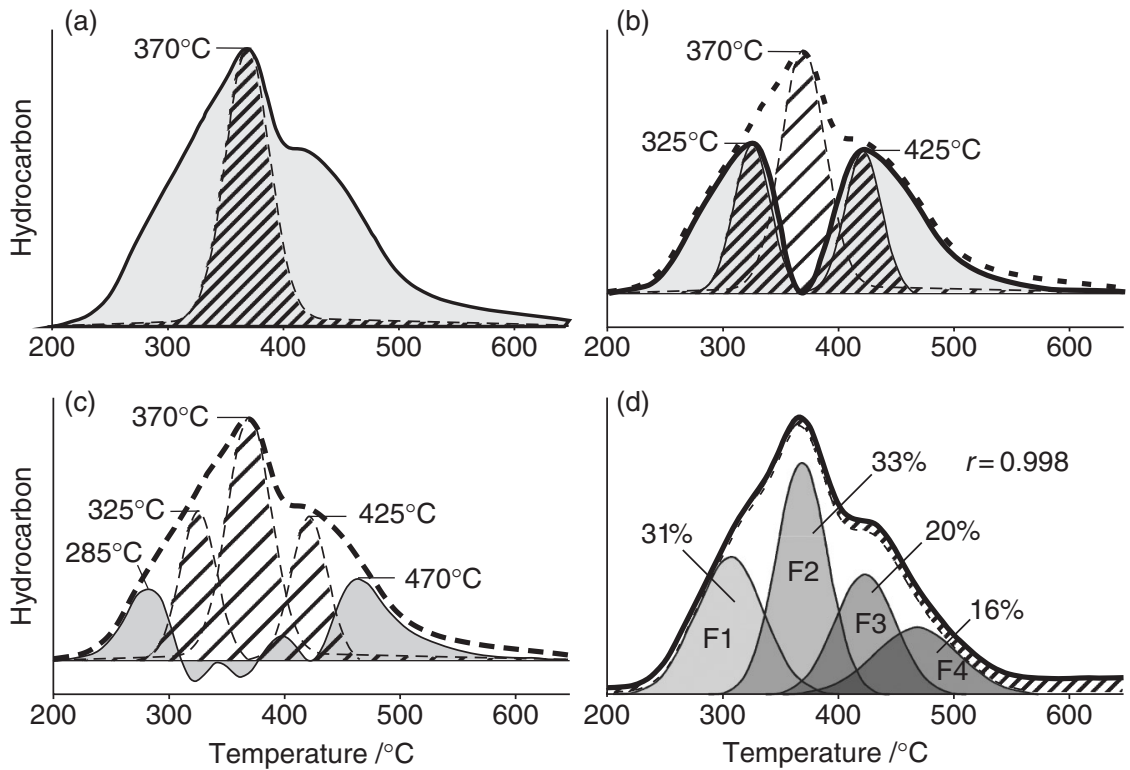

globally confirmed at the soil profile scale (Table 3). The F1 contribution decreases gradually from $35 \%$ in the OL layers to $30 \%$ in the $\mathrm{OF}$ and $\mathrm{OH}$ layers, then abruptly down to $15 \%$ in the organo-mineral (A) horizons. Decreasing with depth, the F2 contribution can distinguish residual plant layers (OL and OF; about $30 \%$ ) from humic $(\mathrm{OH})$ and organo-mineral (A) layers (about 20\%). The F3 and F4 yields tend to increase with depth from the organic to the organo-mineral layers: from 20 to $40 \%$ and from $15 \%$ to more than $20 \%$, for F3 and F4, respectively.

These results show the distinctive signatures of the various soil horizons (Figure 3c,d). The first three components (F1 to F3) can be used to separate plant litters and humic and organo-mineral layers (Figure 3c). By grouping components F1 and F2 and introducing F4, major horizons can be discriminated (Figure 3d), since the cumulative yields of F1 and F2 gradually decrease from OL (plant litter; 60-80\%) to $\mathrm{OF}$ horizons $(50-70 \%)$ and humic $(\mathrm{OH})$ layers $(50-60 \%)$ as $\mathrm{F} 3$ increases from 10 to $40 \%$. This trend continues in organomineral (A) horizons, but is also coupled to an increase of F4 that shifts the values towards the diagram centre (Figure $3 \mathrm{~d}$ ).

\section{Discussion}

Elementary and molecular analyses allow (i) study of the mineralization and humification processes in soil profiles, and (ii) definition of various biomarkers of the origin (e.g. organisms or tissues) or pedogenetic control (e.g. climate or hydrological conditions) of soil OM (e.g. Kögel-Knabner, 2000). However, such high-precision analyses only relate to a small proportion of the whole soil OM. On the other hand, the basic Rock-Eval parameters, i.e. Tpeak and HI, can be used for the bulk characterization of OM, but they are badly adapted to the study of immature OM from recent surficial deposits, e.g. soils and Holocene deposits (Disnar et al., 2003). However, the measured signals, i.e. S2 to S4 curves, reflect significant differences. Thus, at the soil profile scale, the S2 curve shape evolves progressively with depth from multilobed signals (for OL and OF horizons) to unimodal signals (for A, $\mathrm{C}$ and $\mathrm{R}$ samples; Figure 1).

These pyrograms can be deconvoluted using four Gaussian elementary signals (Figure 4). Components F1 to F4 correspond to the various components of $\mathrm{S} 2$ curves that can be recognized as simple shoulders or as dominant components. These various components have been attributed to four major classes of organic constituents, distinguished by their pyrolysis temperatures (Disnar et al., 2003). With its Tpeak less than $360^{\circ} \mathrm{C}, \mathrm{F} 1$ is related to little resistant 'bio-macromolecules' typical of fresh plant material and soil litter. Component F2 which reaches a maximum at $c .360-370^{\circ} \mathrm{C}$ is characteristic of litter and can be related to abundant and rather resistant biopolymers such as lignin and cellulose. Characteristic of the humic layers, component F3 (Tpeaks of c. $420^{\circ} \mathrm{C}$ or of $430-440^{\circ} \mathrm{C}$ ) can be related to immature 'geo-macromolecules' (or humic substances sensu lato). With Tpeak values greater than $470^{\circ} \mathrm{C}$, usually characteristic of thermally mature organic constituents (Espitalié et al., 1985), component F4 is accordingly rather well-represented in deeper soil horizons from the pyrolysis of refractory organic fractions (mature 'geomacromolecules'). This last fraction combines numerous constituents of various origin and/or nature: (i) naturally stable biological compounds, (ii) organic constituents stabilized by physico-chemical processes such as pedogenesis, adsorption on to clays, retention by the mineral matrix, previous burial diagenesis (Balesdent \& Guillet, 1982; Baldock \& Skjemstad, 2000; Kaiser \& Guggenberger, 2000; Salmon et al., 2000; Zegouagh et al., 2004), and (iii) residues of fires and some anthropogenic pollutants like soot, i.e. components 

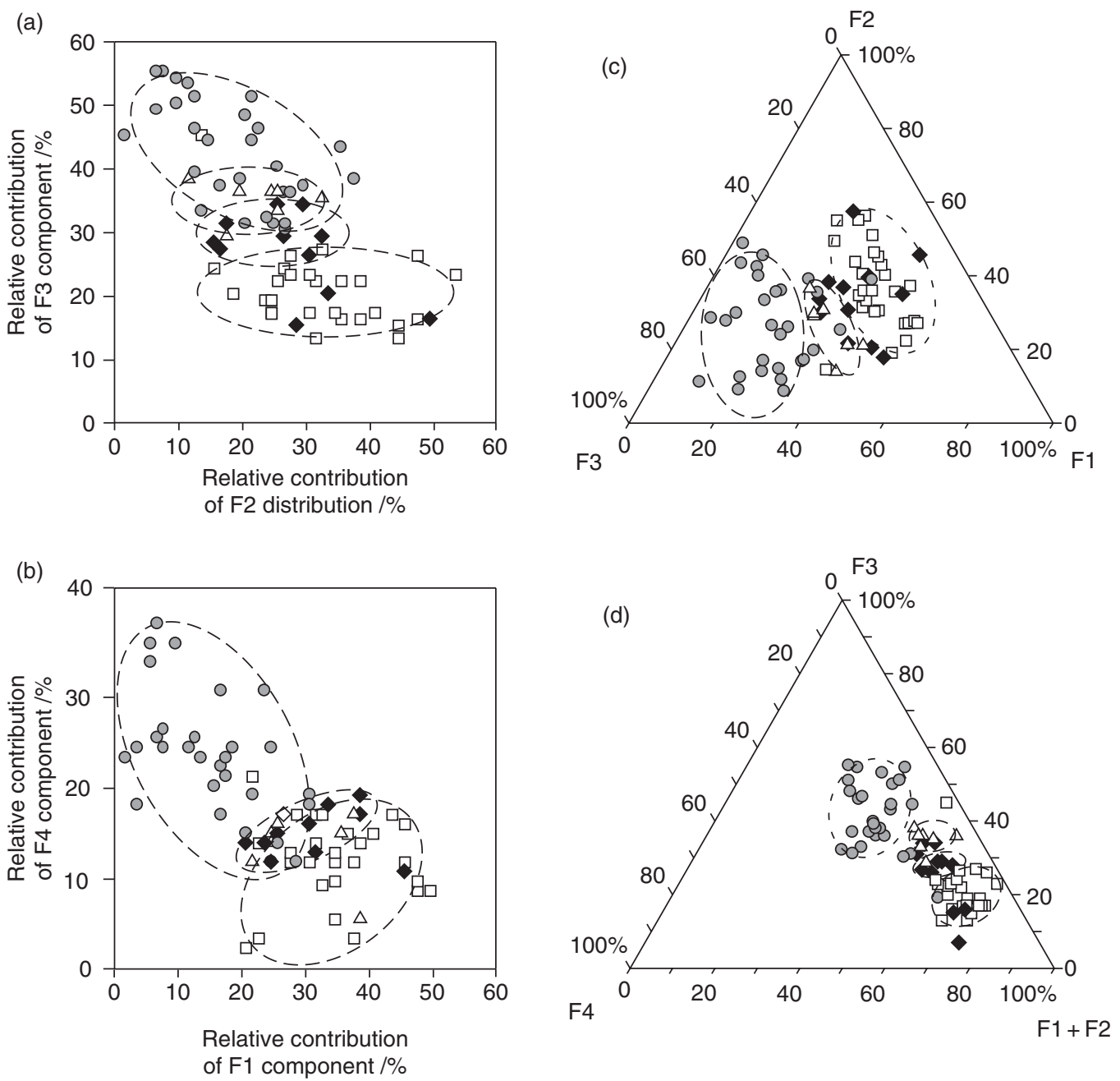

Figure 3 Results of the mathematical deconvolution from 76 soil samples (O and A layers) from Haute-Normandie and Haute-Provence. (a) Relationship between stable 'bio-macromolecules' (F2) and immature 'geo-macromolecules' (F3). (b) Relationship between labile 'bio-macromolecules' (F1) and refractory 'geo-macromolecules' (F4). (c) Relationship between components F1, F2 and F3 (i.e. immature OM). (d) Relationship between components F1 + F2, F3 and F4 (i.e. the whole soil OM). Ellipses do not represent confidence intervals, but are for guidance. $\square$, OL; $\mathrm{OF} ; \triangle, \mathrm{OH} ; \mathrm{O}, \mathrm{A}$.

now collectively called 'black carbon' (Golberg, 1985; Schmidt \& Noack, 2000).

On the other hand, the proposed approach does not allow identification or quantification of individual chemical compounds, because: (i) it is obvious that the diversity of biological compounds, plus their soil derivatives, is much greater than four components; (ii) as made clear in Figure 1, the major plant constituents lignin and cellulose can effectively decompose in the same temperature range (around $370^{\circ} \mathrm{C}$ ); (iii) the results clearly show that all the elementary components (F1 to F4) are found, though in variable intensity, in all deconvoluted $\mathrm{S} 2$ curves. For example, the 'geo-macromolecules' (F4) signal is also found in S2 curves from biological compounds and plant litter and the 'bio-macromolecules' (F1 and F2) signals are also present in curves from deep soil horizon samples. Thus, the individual areas of each $\mathrm{F} 1$ to $\mathrm{F} 4$ component are only proportional to the contribution of the corresponding organic fraction to the initial S2 signal. The S2 curve deconvolution allows quantification of the relative contribution of the four constituents defined by their pyrolysis temperature (i.e. Tpeak).

We studied the pyrograms from organic (OL, OF), humic $(\mathrm{OH})$, organo-mineral $(\mathrm{A})$ and mineral $(\mathrm{C}, \mathrm{R})$ samples. Only a few types of $\mathrm{S} 2$ curve did not give a proper goodness-of-fit by deconvolution with the four above-defined components. Thus, our Ferralitic Arenosol required two other elementary Gaussian components (around $280^{\circ} \mathrm{C}$ and $560^{\circ} \mathrm{C}$, respectively) to describe the $\mathrm{S} 2$ curves obtained. These two components could represent a labile fraction of 'bio-macromolecules' and a very refractory organic fraction, the nature of which is currently unknown to us. In addition, the deconvolution technique is not usable with curves obtained from weathered (C) and unweathered $(\mathrm{R})$ parent rocks, because the whole signal 
Table 3 Means (standard errors in parentheses) of each horizon for the whole of the samples studied (upper part), and some representative results from two fields in experimental catchments (lower part): Le Brusquet (Br) and Le Laval (La). R = F1/F2 ratio; I = log[(F1 + F2)/F3]

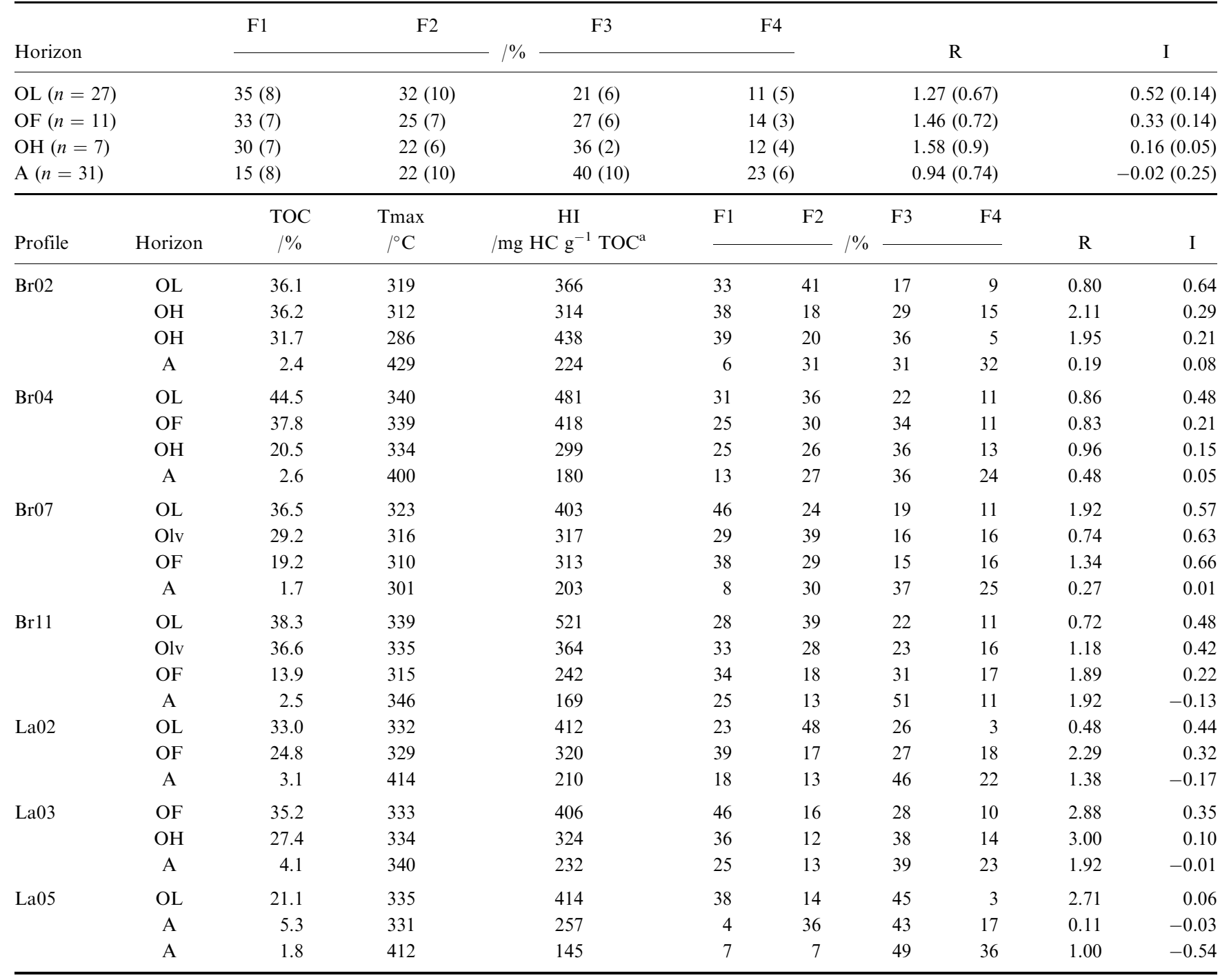

${ }^{\mathrm{a}} \mathrm{HC}$, hydrocarbon.

maximizes at Tpeak temperatures $>450^{\circ} \mathrm{C}$. Moreover, for these geological samples, a single Tpeak-centred component is enough to describe the $\mathrm{S} 2$ curves.

The results obtained from 76 organic $(\mathrm{O})$ and organo-mineral (A) samples, i.e. grassland and forest soils from HauteNormandie and Haute-Provence, show that a morphological analysis of S2 curves can be used to characterize immature soil $\mathrm{OM}$ and its variations down soil profiles, and supplements its geochemical characterization by classical parameters such as Tpeaks and HI values. Thus, the contribution of 'bio-macromolecules' (the sum of F1 and F2 signals) exceeds $50 \%$ in the OL and OF layers. The slight decrease of the less resistant 'bio-macromolecules' (F1) observed in the underlying layers is attributed to partial mineralization and enzymatic degradation, which are particularly active in OF horizons (Kögel-Knabner, 1993). The contribution of the resistant 'biomacromolecules' (F2) remains at the same value in the plant layers (OL, OF), but decreases sharply in the humic layers $(\mathrm{OH})$, and even more in deeper horizons (A and $\mathrm{B})$, to the benefit of immature 'geo-macromolecules' (F3; Figures 3a and 4). The changes in $\mathrm{OM}$ composition are mostly shown by a decrease in the average contribution of 'bio-macromolecules', i.e. F1 and F2. The sum of the contribution of these two classes, which represented about half of the $\mathrm{S} 2$ signals, falls to $38 \%$ in organo-mineral samples. A great part of this decrease affects the less resistant 'bio-macromolecules' (F1), and is accompanied by an increasing contribution of the more refractory fraction $\mathrm{F} 4$ (Figure 3b). 

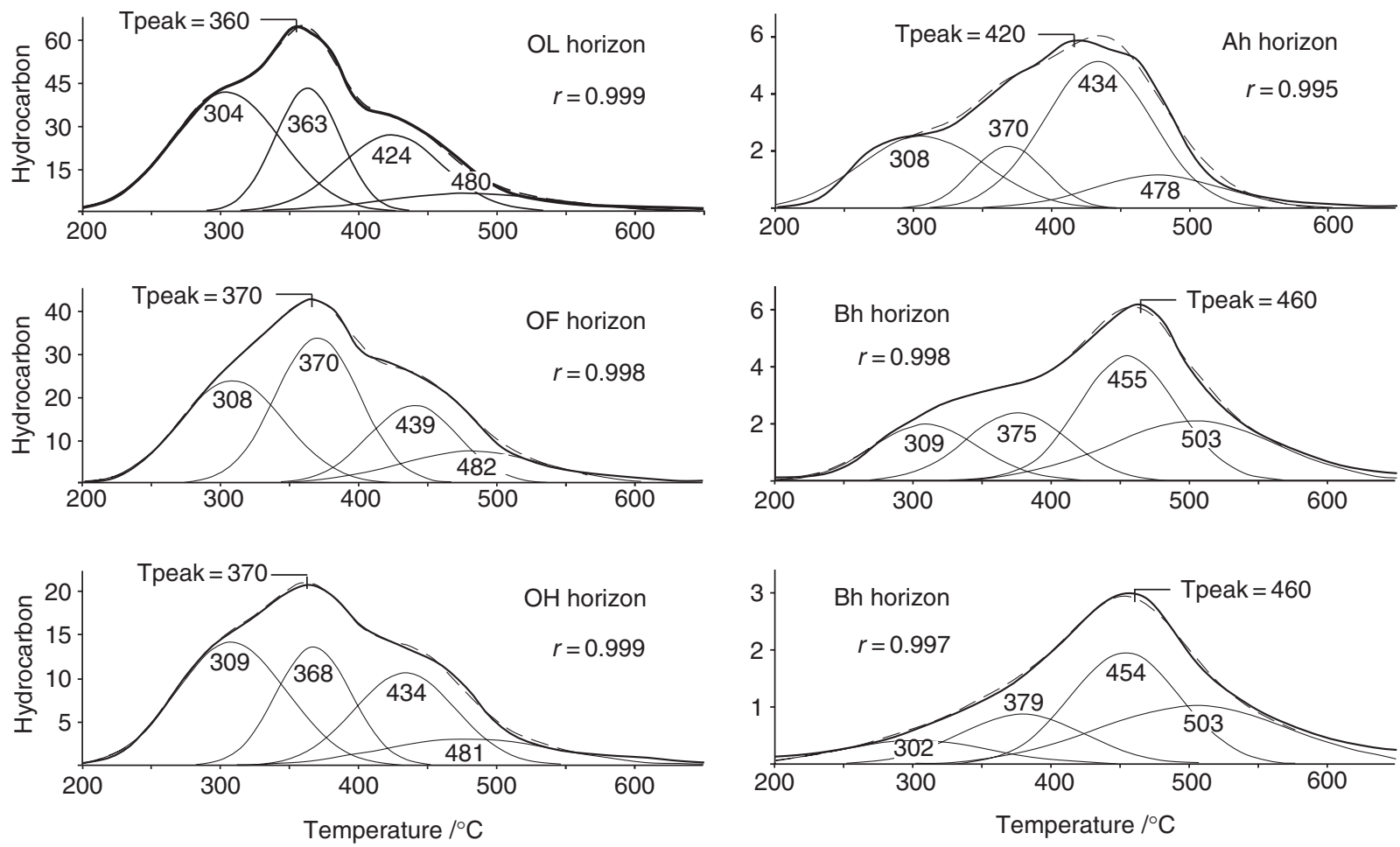

Figure 4 Results of the deconvolution of S2 signals from Podzol horizons showing the relative variations of F1 to F4 components with depth. Note the progressive evolution of the relative contributions with depth. Dotted curve: original S2 signal. The numeric labels on the $y$-axis measure quantity of hydrocarbon released (arbitrary unit).

These general trends are globally respected for each soil profile. On the other hand, one of the components, in particular F1, often presents an 'anomaly' for some horizons (Table 3). In our opinion, this can result from local impact of pedogenetic controls, i.e. nature and density of the plant cover, climate, topography and hydrological context. In other words, (i) the general trends, i.e. relative increase or decrease of $\mathrm{F} 1$ to F4 contributions with depth, reflect the changes of OM composition related to mineralization and humification processes, but (ii) the absolute values depend on the local parameters controlling the nature and the amounts of biological inputs and/or the humification and mineralization yields. Thus, the complex overlaps of means from each horizon can result from a sampling in various local settings (Table 1), as shown by the following examples. In the first example, we discuss some factors controlling the relative contributions of bio-macromolecules, i.e. F1/F2 ratio. In the second, we study the relative contributions of bio- and geo-macromolecules in relation to (i) the biological inputs in soils and (ii) the early diagenesis in Holocene sedimentary deposits.

\section{Relative contributions of two 'bio-macromolecule' classes}

The relative evolution of the two 'bio-macromolecule' classes is illustrated by the $\mathrm{F} 1 / \mathrm{F} 2$ ratio. It shows significant variations: from 0.5 to 2.7 (mean $1.4 \pm 0.7$ ) for the organic horizon
(O) and from 0.1 to $3.5(0.9 \pm 0.7)$ for the organo-mineral horizon A (Table 3 and Figure 5). Some hypotheses can be formulated to explain these differences. First, grassland soils globally present larger $\mathrm{F} 1 / \mathrm{F} 2$ ratios (from 1.2 to $2.7 ; 1.9 \pm 0.6$ ) than forest soils (from 0.7 to $2.7 ; 1.3 \pm 0.7$ ). This difference probably arises from the different proportions of OM from herbaceous plants (rich in less resistant 'bio-macromolecules') and tree tissues (rich in more resistant ligno-cellulose). In addition, the mineralization and humification processes can also induce $\mathrm{F} 1 / \mathrm{F} 2$ ratio variations (Table 3 ). At the soil profile scale, the three decayed litters studied are characterized by small $\mathrm{F} 1 / \mathrm{F} 2$ ratios $(0.5,0.7$ and 1.2 , respectively) whereas humic layers show generally large $\mathrm{F} 1 / \mathrm{F} 2$ ratios (1-3; $1.6 \pm 0.9)$. These variations are likely explained by a good preservation of resistant 'bio-macromolecules' in litter and by their transformation in humic layers. The differences in the F1/ F2 ratio can thus be associated with the local factors, which depend on the differences in the vegetal sources, on the preservation or selective degradation of organic constituents, and on interactions with the mineral matrix.

\section{Relative contributions of both immature bio- and geo-macromolecules}

The origin and thermal resistance (measured by Tpeak) of organic constituents responsible for F1 to F4 distributions 
(a)

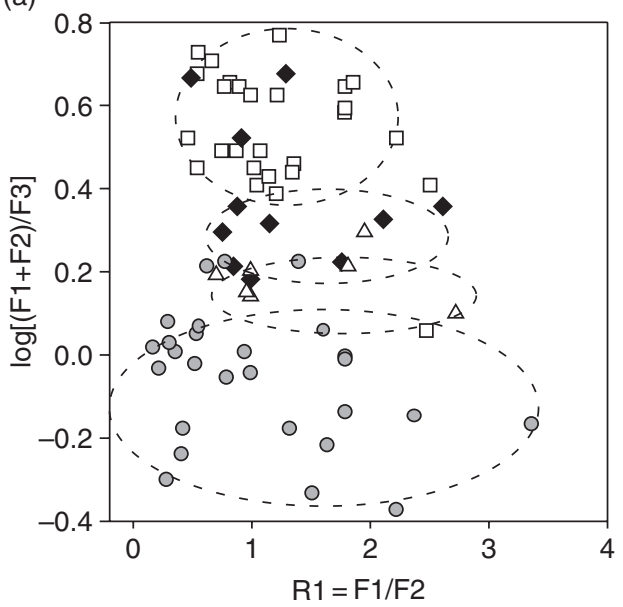

(b)

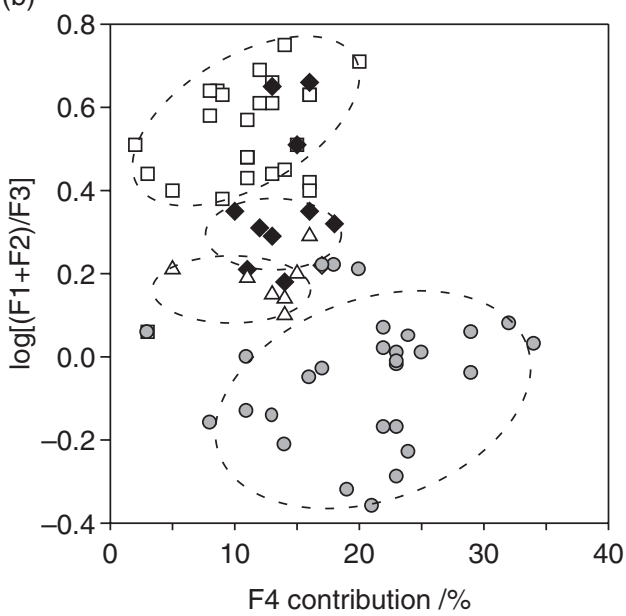

Figure 5 Signatures of the 76 representative soil samples with results of mathematical decomposition (ellipses are for guidance). (a) Relationship between $\mathrm{F} 1 / \mathrm{F} 2$ ratio and $\log [(\mathrm{F} 1+\mathrm{F} 2) / \mathrm{F} 3]$ index emphasizing the immature fraction. (b) Relationship between F4 values and $\log [(\mathrm{F} 1+\mathrm{F} 2) / \mathrm{F} 3]$ index showing the signature of the whole soil OM. $\square$, OL; $\diamond$, OF; $\triangle$, OH; O, A.

allows us to distinguish two main organic fractions present in soils: (i) a thermally immature fraction (Tpeak $<470^{\circ} \mathrm{C}$, i.e. $\mathrm{F} 1, \mathrm{~F} 2$ and F3) and (ii) a refractory fraction (Tpeak $>470^{\circ} \mathrm{C}$; F4). The distinction of these two main fractions is critical to the study of OM evolution, because they react differently during pedogenic transformations. On the other hand, since the sum of F1, F2 and F3 represents between 70 and $95 \%$ of the initial S2 peak, OM evolution can be described by the variations of the relative contribution of 'bio-macromolecules' (F1 and F2) and immature 'geo-macromolecules' (F3).

We propose to use the $\log [(\mathrm{F} 1+\mathrm{F} 2) / \mathrm{F} 3]$ index to quantify the degradation of immature OM. First, it illustrates the relative importance of biological inputs ('bio-macromolecules': F1 and F2) versus the main components of humic layers (immature 'geo-macromolecules': F3). In agreement with this theoretical aspect, the index values show a progressive decrease down soil profiles (Table 3). This trend is emphasized by mean values calculated for each layer (Table 3). The greatest values are associated with fresh or little-degraded plant fragments (initial stage). The smallest values, associated to the organo-mineral horizons (Table 3), are comparable to those of Holocene deposits (Table 4). Lastly, elemental analyses indicate a relation between the $\log [(\mathrm{F} 1+\mathrm{F} 2) / \mathrm{F} 3]$ index and the $\mathrm{C} / \mathrm{N}$ ratios (Figure 6), which suggests a relation to the mineralization of biological inputs. Additionally, the $\log [(\mathrm{F} 1+\mathrm{F} 2) / \mathrm{F} 3]$ index is correlated to the HI index $(r=0.88)$, which measures the quantity of hydrocarbons released per gram of TOC (Figure 7a). This relationship reflects the dehydrogenation of $\mathrm{OM}$ with progressive consumption of 'bio-macromolecules' during OM transformation in the soil profiles (Disnar et al., 2003). The information provided by the $\log [(\mathrm{F} 1+\mathrm{F} 2) / \mathrm{F} 3]$ index combines two 'RockEval' pyrolysis conventional parameters: as $\mathrm{HI}$, it provides a measure of the degree of degradation of immature soil OM, and as Tpeak, it distinguishes the main soil layers (Figure 7b). Applications of this index are illustrated below showing the influence of the plant cover density and of local hydrological conditions, respectively.

\section{Examples of application of the $\log [(F 1+F 2) / F 3]$ index}

The first example concerns two experimental sites ('basins') located in the south of France (Haute-Provence). The Brusquet (Br) and Laval (La) basins are less than $3 \mathrm{~km}$ apart and differ only in the nature and density of their plant cover (Table 1). The $\log [(\mathrm{F} 1+\mathrm{F} 2) / \mathrm{F} 3]$ index values are systematically less for soils under sparse vegetation (i.e. Laval) than under dense plant cover (i.e. Brusquet; Table 3 and Figure 8). As shown by the greater ratios, the Brusquet catchment soils are enriched in 'bio-macromolecules' compared with those of the Laval. The major abiotic factors (climate, substratum, etc.) being similar, only the difference in the primary organic productivity related to surficial biological inputs (i.e. the type of vegetation) provides the difference in the supply of 'bio-macromolecules'. Absolute index values can also reflect the importance of surficial biological inputs, especially in OL horizons.

The second example concerns a Holocene alluvial core (BLP2) sampled in the Lower Seine Valley. The $\log [(\mathrm{F} 1+\mathrm{F} 2) / \mathrm{F} 3]$ index varies from -0.2 to 0.5 for the whole set of fluvio-palustrine samples. Mean values differ for the different sedimentary facies (Table 4 ). The clayey peaty deposits present homogeneous values $(0.1-0.2 ; 0.16 \pm 0.05)$ compared with other facies: from -0.2 to 0.5 for peats $(0.07 \pm 0.23) ; 0.2-0.4$ for clayey silts $(0.33 \pm 0.12) ;-0.2$ to -0.05 for lower sandy silts $(-0.12 \pm 0.06)$. Differences are greater for the peaty deposits than for the detrital facies (i.e. clayey peat, clayey and sandy loams). Large contributions of 'bio-macromolecules' depicted by rather greater ratios (c. 0.4) indicate good OM preservation, whereas the small ratios $(c .-0.1)$ of others reveal greater degradation. The age 
Table 4 Some representative results from Holocene fluvio-palustrine deposits (BLP2 core). $\mathrm{R}=\mathrm{F} 1 / \mathrm{F} 2$ ratio; $\mathrm{I}=\log [(\mathrm{F} 1+\mathrm{F} 2) / \mathrm{F} 3]$

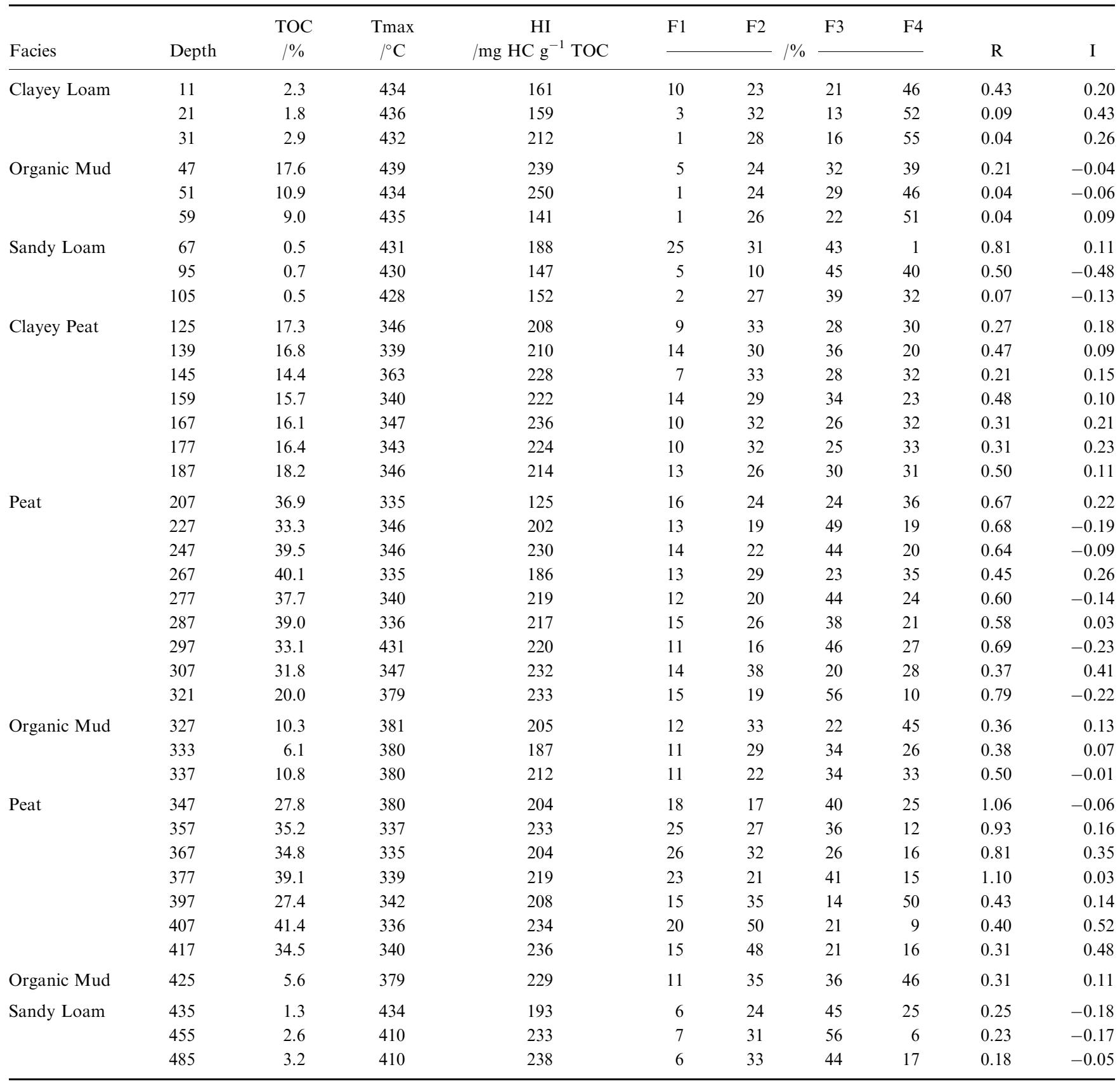

of the deposits, i.e. diagenesis duration, cannot explain these differences, since some old peaty samples give large ratios (comparable with present-day forest litters), whereas younger samples give small ratios (comparable to the organo-mineral soil horizons). Thus, only changes of biological inputs or merely of conditions of OM degradation could explain these large differences. In the area studied, i.e. Lower Seine Valley, these changes are related directly to Holocene fluctuations in local hydrological factors (e.g. sea level changes and induced water tables; Sebag, 2002).

\section{Conclusions}

The present study illustrates some possibilities offered by Rock-Eval pyrolysis to obtain fundamental quantitative and qualitative information on immature OM rapidly. In addition to the basic information that is given by the classical RE parameters (namely TOC, HI and Tpeak), further insight into soil OM composition can be obtained by mathematical deconvolution of the S2 curve into elementary signals. All the pyrograms obtained from a large set of samples taken from 


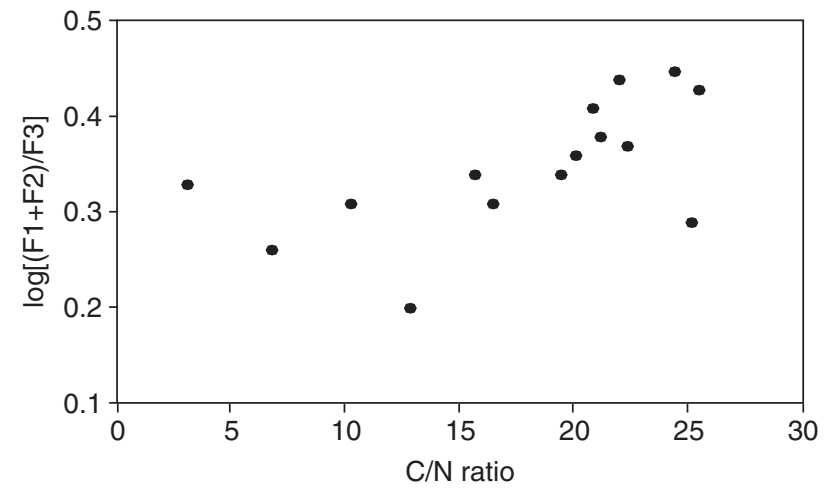

Figure 6 Relationship between $\mathrm{C} / \mathrm{N}$ ratio and $\log [(\mathrm{F} 1+\mathrm{F} 2) / \mathrm{F} 3]$ index (for 15 peat samples in various states of degradation).

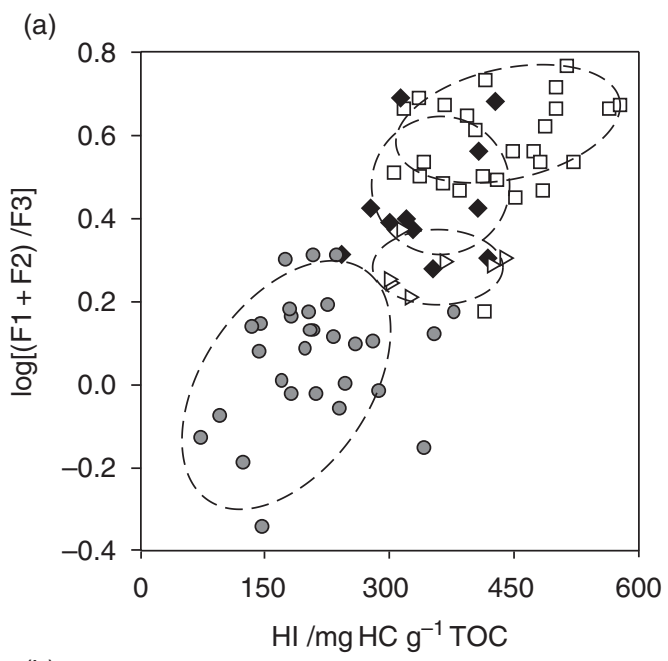

(b)

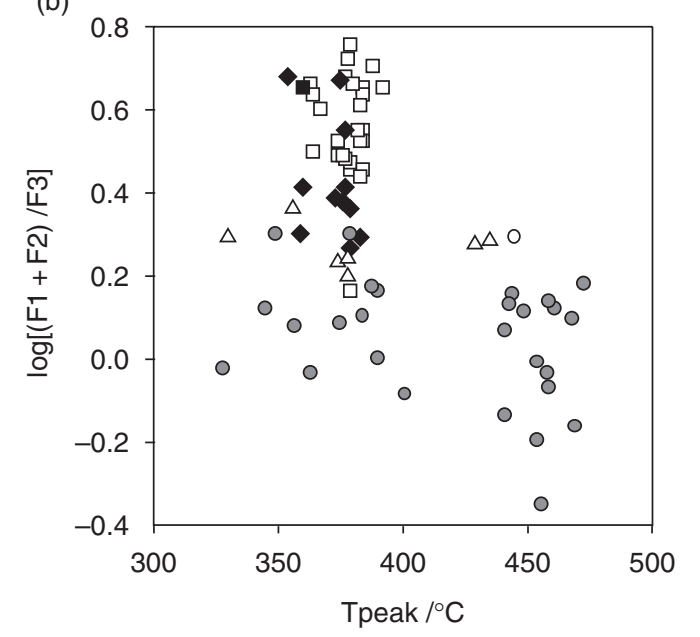

Figure 7 Relationship between conventional parameters and $\log [(\mathrm{F} 1+\mathrm{F} 2) / \mathrm{F} 3]$ (for 76 representative soil samples). (a) Relation between $\mathrm{HI}$ and $\log [(\mathrm{F} 1+\mathrm{F} 2) / \mathrm{F} 3] \quad(r=0.88)$. (b) Relationship between Tpeak and $\log [(\mathrm{F} 1+\mathrm{F} 2) / \mathrm{F} 3]$. $\square, \mathrm{OL} ; \diamond, \mathrm{OF} ; \triangle, \mathrm{OH} ; \mathrm{O}, \mathrm{A}$.

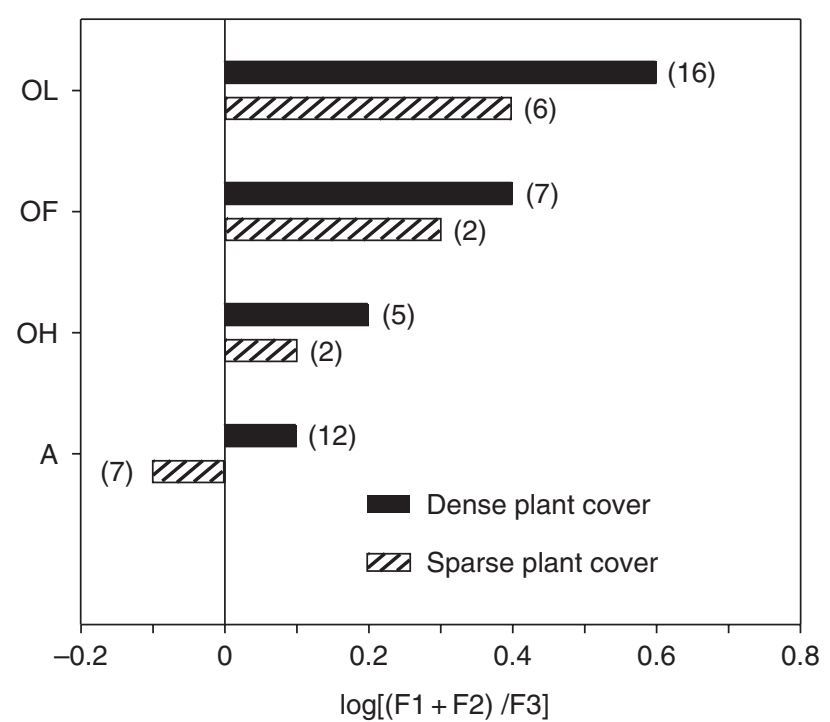

Figure $8 \log [(\mathrm{F} 1+\mathrm{F} 2) / \mathrm{F} 3]$ index mean values for soil horizons in $\mathrm{Le}$ Brusquet (dense plant cover: 40 samples) and Le Laval (sparse plant cover: 17 samples) catchment areas. The sample numbers are quoted in parentheses.

different soils and sediments can be deconvoluted into the same four components (F1 to F4). The results show that the relative contributions of the elementary signals can be used to characterize OM contents, to follow their transformations in soil profiles and to quantify their evolution. In two small field studies, the new parameters, i.e. relative contributions or calculated index, have been used to illustrate the importance of two major factors on soil OM quality, namely the abundance and the degree of preservation of the primary vegetal inputs. The principal interest of this approach is that the new parameters can be compared independently of the origin, the nature and the age of the samples. This type of bulk characterization is particularly useful when the nature of biological inputs and conditions of degradation are poorly known, e.g. in sedimentological studies and palaeoenvironmental reconstructions.

\section{Acknowledgements}

This work is a contribution to the research programmes of the UMR $6113 \mathrm{CNRS} /$ ISTO and to the programme 'Influence de l'érosion sur les flux de matière organique fossile dans les géosystèmes continentaux actuels: bassins expérimentaux de Draix, Alpes de Haute Provence, France' (INSU/PNSE). Measurements from the Draix experimental catchments were made as part of GIS 'Bassins de Draix: mesure de l'érosion en montagne' (CEMAGREF, Grenoble). Measurements from the Haute-Normandie soils were made as part of the Projet Collectif de Recherche 'Les paysages et les hommes en basse vallée de la Seine depuis 10.000 ans' (UMR 6143 CNRS/M2C) funded by DRAC - Haute-Normandie and DIREN - Haute- 
Normandie, by the Conseil Regional de Haute-Normandie, and by five mining companies $(\mathrm{CBN}, \mathrm{FCH}$, Lafarge Granulats, Morillon Corvol and STREF). We thank D. Kéravis and J.P. Bakyono for their assistance in laboratory analysis. We thank also H. Noël, S. Ogier, P. Loveland and anonymous reviewers for their help, remarks and advice.

\section{References}

AFES 1995. Référentiel Pédologique. Techniques et Pratiques. INRA Editions, Paris.

Ariztegui, D., Chondrogianni, C., Lafargue, E. \& McKenzie, J.A. 1996. Compositional variations in sedimentary organic matter in Lake Albano Holocene record: ecosystem reaction to environmental changes. In: Palaeoenvironmental Analysis of Italian Crater Lake and Adriatic Sediments (eds P. Guilizzoni \& F. Oldfield). International Journal of Limnology, 55, 111-117.

Baldock, J.A. \& Skjemstad, J.O. 2000. Role of the soil matrix and minerals in protecting natural organic materials against biological attack. Organic Geochemistry, 31, 697-710.

Balesdent, J. \& Guillet, B. 1982. Les datations par le ${ }^{14} \mathrm{C}$ des matières organiques des sols. Contribution à l'étude de l'humification et du renouvellement des substances humiques. Science du Sol, 2, 93-111.

Di Giovanni, C., Disnar, J.R., Bichet, V., Campy, M. \& Guillet, B. 1998. Geochemical characterization of soil organic matter and variability of a postglacial detritical organic supply (Chaillexon Lake, France). Earth Surface Processes and Landforms, 23, 1057-1069.

Di Giovanni, C., Disnar, J.R., Campy, M. \& Macaire, J.J. 1999. Variability of the ancient organic supply in modern humus. Analusis, 27, 398-402.

Disnar, J.R. 1994. Determination of maximum paleotemperatures of burial (MPTB) of sedimentary rocks from pyrolysis data on the associated organic matter: basic principles and practical application. Chemical Geology, 118, 289-299.

Disnar, J.R. \& Trichet, J. 1984. The influence of various divalent cations $\left(\mathrm{UO}_{2}{ }^{2+}, \mathrm{Cu}^{2+}, \mathrm{Pb}^{2+}, \mathrm{Co}^{2+}, \mathrm{Ni}^{2+}, \mathrm{Zn}^{2+}, \mathrm{Mn}^{2+}\right)$ on thermally induced evolution of organic matter isolated from an algal mat. Organic Geochemistry, 6, 865-874.

Disnar, J.R., Guillet, B., Keravis, D., Massif, R. \& Di Giovanni, C. 2000. Soil organic matter (SOM) characterization by Rock-Eval pyrolysis: main classical parameters. In: Entering the Third Millennium with a Common Approach to Humic Substances and Organic Matter in Water, Soil and Sediments (Proceedings of the International Humic Substances Society 10), pp. 1211-1214. Association pour la Promotion du Génie des Procédés, Toulouse.

Disnar, J.R., Guillet, B., Kéravis, D., Di Giovanni, C. \& Sebag, D. 2003. Soil organic matter (SOM) characterisation by Rock-Eval pyrolysis: main possibilities and limitations. Organic Geochemistry, 34, 327-343.

Espitalié, J., Laporte, J.L., Madec, M., Marquis, F., Leplat, P., Paulet, J. \& Boutefeu, A. 1977. Méthode rapide de caractérisation des rochemères, de leur potentiel pétrolier et de leur degré d'évolution. Revue de l'Institut Français du Pétrole, 32, 23-42.

Espitalié, J., Deroo, G. \& Marquis, F. 1985. La pyrolyse Rock-Eval et ses applications. $1^{\text {ère }}$ partie. Revue de l'Institut Français du Pétrole, 40, 563-579.
FAO 1994. World Reference Base for Soil Resources. FAO, Land and Water Development Division, Rome.

Golberg, E.D. 1985. Black Carbon in the Environment. Wiley, New York.

Kaiser, K. \& Guggenberger, G. 2000. The role of DOM sorption to the mineral surfaces in the preservation of organic matter in soils. Organic Geochemistry, 31, 711-725.

Kögel-Knabner, I. 1993. Biodegradation and humification: processes in forest soils. In: Soil Biochemistry (eds J.M. Bollag \& G. Stotzky), pp. 101-135. Dekker, New York.

Kögel-Knabner, I. 2000. Analytical approaches for characterizing soil organic matter. Organic Geochemistry, 31, 609-625.

Lafargue, E., Marquis, F. \& Pillot, D. 1998. Rock-Eval 6 applications in hydrocarbon exploration, production, and soil contamination studies. Revue de l'Institut Français du Pétrole, 53, 421-437.

Leinweber, P. \& Schulten, H.R. 1999. Advances in analytical pyrolysis of soil organic matter. Journal of Analytical and Applied Pyrolysis, 49, 359-383.

Lüniger, G. \& Schwark, L. 2002. Characterisation of sedimentary matter by bulk and molecular geochemical proxies: an example from Oligocene Maar-Type Lake Enspel, Germany. Organic Geochemistry, 148, 277-288.

Magrini, K.A., Evans, R.J., Hoover, C.M., Elam, C.C. \& Davis, M.F. 2002. Use of pyrolysis molecular beam mass spectrometry (pyMBMS) to characterize forest soil carbon: method and preliminary results. Environmental Pollution, 116, 255-268.

Noël, H., Garbolino, E., Brauer, A., Lallier-Vergès, E., de Beaulieu, J.L. \& Disnar, J.R. 2001. Human impact and soil erosion during the last $5000 \mathrm{yrs}$ as recorded in lacustrine sedimentary organic matter at Lac d'Annecy, the French Alps. Journal of Paleolimnology, 25, 229-244.

Rumpel, C., Janikb, L.J., Skjemstad, J.O. \& Kögel-Knabner, I. 2001. Quantification of carbon derived from lignite in soils using midinfrared spectroscopy and partial least squares. Organic Geochemistry, 32, 831-839.

Salmon, V., Derenne, S., Lallier-Vergès, E., Largeau, C. \& Beaudoin, B. 2000. Protection of organic matter by mineral matrix in a Cenomanian black shale. Organic Geochemistry, 31, 463-474.

Schmidt, M.W.I. \& Noack, A.G. 2000. Black carbon in soils and sediments: analysis, distribution, implications and current challenges. Global Biogeochemical Cycles, 14, 777-793.

Sebag, D. 2002. Apports de la matière organique pour la reconstitution des paléoenvironnements holocènes de la basse vallée de la Seine. Fluctuations des conditions hydrologiques locales et environnements de dépôt. Thèse de doctorat, Université de Rouen.

Sifeddine, A., Laggoun-Défarge, F., Lallier-Vergès, E., Disnar, J.R., Williamson, D., Gasse, F. \& Gibert, E. 1995. La sédimentation organique lacustre en zone tropicale sud au cours des 36000 dernières années (Lac Tritrivakely, Madagascar). Comptes Rendus de l'Académie des Sciences, Paris, 321, 385-391.

Tissot, B. \& Welte, D.H. 1984. Petroleum Formation and Occurrence. Springer, Berlin.

Zegouagh, Y., Derenne, S., Dignac, M.F., Baruiso, E., Mariotti, A. \& Largeau, C. 2004. Demineralisation of a crop soil by mild hydrofluoric acid treatment. Influence on organic matter composition and pyrolysis. Journal of Analytical and Applied Pyrolysis, 71, 119-135. 